Margarita Kuyumdzhieva (Sofia)

\title{
ImAging Evil in The First Chapters of Genesis: TeXts behind The IMAges in EAstern OrthodoX Art
}

It is a well-known fact that the Bible is the metatext of the Christian civilization, the foundation of the Christian worldview. It has given rise to a large part of the Christian imagery we know today from icons, frescoes in churches and illustrated manuscripts. Yet, the Biblical text is not the exclusive supplementary source for the images in medieval art. Sometimes these images, no matter Eastern orthodox or Western in their origin, owe their emergence and visual characteristics to different homiletic, liturgical, and, above all, apocryphal texts ${ }^{1}$. In Christian art the image not only illustrates specific text, but it may also act as a form of exegesis. In these cases it exceeds its specific textual basis adding motifs from other written sources in order to express a particular idea. Thus, the image superimposes new semantic levels on the literary subject, enriching it with ecclesiological, didactic, political and ideological aspects. This kind of elaborated role of the image is a product of a deep theological knowledge, thus representing the views of a highly educated

\footnotetext{
${ }^{1}$ The literature on the links between apocryphal texts and religious images is rich and here only some of the publications will be quoted: D. CARTLIDGe, J. Elliott, Art and the Christian Apocrypha, London 2001; J. Lafontaine-Dosogne, Iconography of the Cycle of the Life of the Virgin, [in:] The Kariye Djami, IV. Studies in the Art of the Kariye Djami and its Intellectual Background, ed. P. Underwood, Princeton 1975, p. 161-194; EADEM, Iconography of the Cycle of the Infancy of Christ, [in:] The Kariye Djami..., p. 195-241; N. Thiery, L'illustration des apocryphes dans les églises de Cappadoce, Apocr 2, 1991, p. 217-248; E. Bakalova, Principles of Visualization of the Pseudo-Canonical Texts in the Art of the Byzantine Commonwealth, [in:] Biblia Slavorum Apocryphorum II. Novum Testamentum, ed. G. Minczew, M. SкоwroneK, I. Petrov, Łódź 2009, p. 167-189; Е. БАКАловА, За апотропейната сила на Божието слово и образ (легендата за Авгар в изкуството), [in:] Средновековният човек и неговият свят. Сборник в чест на 70-та годишнина на проб. Казимир Попконстантинов, Велико Търново 2014, p. 339-358; in this respect see also the other articles of the proceedings of the series of international conferences Biblia Slavorum Apocryphorum I. Vetus Testamentum. [FE, 4, fasc. VI/VII], Gniezno 2007; Biblia Slavorum Apocryphorum II. Novum Testamentum. Materiały z Międzynarodowej Konferencji Naukowej „Biblia Slavorum Apocryphorum. II. Novum Testamentum” Łódź, 15-17 maja 2009 r., ed. G. Minczew, M. Skowronek, I. Petrov, Łódź 2009; for Byzantine art and its connections with different recensions of the text of the Palaea, see R. STICHEL, Außerkanonische Elemente in byzantinischen Illustrationen des Alten Testaments, RQ 69, 1974, p. 159-181; М. МАРКОвић, Ј. МАрковић, Циклус Генезе и Старозаветне фигуре у параклису Св. Димитрија, [in:] 3идно сликарство манастира Дечана. Грађа и студије, еd. В.Ј. Ђурић, Београд 1995, р. 323-352.
} 
elite. Simultaneously, images can also consign to a layer of ideas - ancient cosmological and ethical models, sometimes originated in pre-biblical mythology, which are distributed through a different kind of literature, the non-canonical texts ${ }^{2}$. This capacity to encompass multiple meanings applies particularly to the images associated with the Old Testament accounts in the Byzantine and Eastern Orthodox art. In the present study, in order to illustrate the idea of this polysemy the focus will be put on the image of evil in the story of Adam and Eve and their children.

In Christian milieu the primary personification of evil is a single personality, known by different names in different traditions. Whether he is called the Devil, Lucifer, Sammael or Satanael, he is the obstructor of the kingdom of God, the one who tempts humans together with his demons in order to turn them away from $\mathrm{God}^{3}$. The biblical text of the Genesis does not refer at all to Satan's figure, nor does it speak of any personified evil interference in the life of the protoplasts. Satan is mentioned numerous times in different context in the New Testament ${ }^{4}$ and following some of these patterns the Church Fathers allude to him often in their works ${ }^{5}$. Yet, in Byzantium, this "learned" notion of Devil never became a systematic teaching, rather consisted of different observations scattered here and there in exegetic, polemic, homiletic or hagiographical writings ${ }^{6}$. At the same time, there exists

\footnotetext{
${ }^{2}$ In literature on the topic, the texts with quasi and non-canonical elements are discussed using different terms - "apocrypha", "pseudoepigrapha", "pseudo-canonical", "parabiblical" or "paratextual" literature, and it seems the terminology is still under clarification, see for example A. Miltenova, Parabiblical (paratextual) literature in Mediterranean World and its Reception in Medieval Bulgaria $\left(10^{\text {th }}-14^{\text {th }} \mathrm{cc}\right.$ ), [in:] Biblia Slavorum Apocryphorum I. Vetus Testamentum [FE, 4, fasc. VI/VII], Gniezno 2007, p. 9-20; А. Милтенова, Маргиналност, интертекстуалност, паратекстуалност в българската сред-

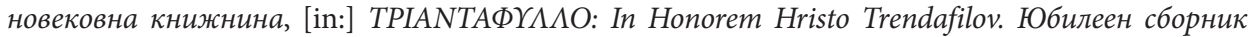
в чест на 60-годишнината на проф. д.фил.н. Христо Трендафилов, еd. V. РАлауотоу, Шумен 2013, p. 128-150 with a brief survey of the development of the terminology in the field.

${ }^{3}$ On the terminology for the evil one in the early Christian writings see F. Gokey, The terminology for the Devil and Evil Spirits in the Apostolic Fathers, Washington 1961.

${ }^{4}$ See for example Luke 10:18, 22:3, 22:31; Mathew 4:10; Marc 4:15; Acts 26:18; 2 Corinthians 11:14, etc.

${ }^{5}$ It could be said that the foundation of Christian demonology was laid by Origen (ca. 185-254) who assembled and elaborated a range of previously existing demonological beliefs. The idea of the Devil as a personal being and a fallen angel was further developed in the early Christian and patristic period, see for example the homily of John Chrysostom Against Those Who Say that Demons Govern Human Affairs, and his two sermons On the Power of Man to Resist the Devil, [in:] Творения Святого Отиа Нашего Иоанна Златоуста, архиепископа Константинопольского, в русском переводе. T. 2, pars. 1, ed. А. Лопухин, Санкт Петербург 1896, p. 270-289. See also J. RusselL, Satan: The Early Christian Tradition, New York 1987; A. Ducellier, Le Diable à Byzance, [in:] Le diable au Moyen Âge: Doctrine, problèmes moraux, représentations. Nouvelle édition, Aix-en-Provence 1979, p. 195-212 http://books.openedition.org/pup/2636.

${ }^{6}$ It is generally accepted among scholars that the notion of Satan in Eastern Orthodox Christianity lacks a systematic theological attention, i.e. there is no fixed teaching or description of the Devil. On this topic, besides the literature quoted in the previous notes, see two short essays, observing mainly the presence of demons in hagiographic literature, but also some aspects of Satan's image in Byzantium:
} 
another, more influential source of information about Satan and this is the great number of apocryphal accounts that retell the Biblical narration of Creation, the life of Adam, Eve and their children, incorporating stories about the origin of Satan, about his role in the creation of the world and in the life of the protoplasts ${ }^{7}$.

In this extensive literary field two main aspects of the Devil can be differentiated - the Devil as a demiurge and the Devil as a tempter. The first one exists in the Christian cosmological concepts of the origin and structure of the world. There, Satan is the most senior among the angels, he was created by God as good, but, because of his free choice to abandon the good, he fell, losing his dignity. While in the moderate Christian dualism Satan was given the role of the creator of the terrestrial world, in radical dualist teachings he was even regarded as a creator of Paradise ${ }^{8}$. Elements and motifs of this cosmic dualism are interrelated to the pseudo-canonical texts, especially those which circulated in the Slavonic milieu as was, for instance the Tale about the combat between Satan and Archangel Michael, even though this example will not be discussed further here, since it has been thoroughly studied with its textual and visual sources ${ }^{9}$.

Satan the tempter, however, will be at the center of our interest. According to a widespread understanding about the Devil, he used the snake to make Adam and Eve transgress God's will. In the Christian exegesis an equation of Satan with the serpent or the dragon exists as well; such motif occurred in the text of the

A. Gulllou, Le diable byzantin, [in:] Polyplevros Nous. Miscellanea für Peter Schreiner zu seinem 60. Geburtstag, ed. C. Scholz, G. MAKRIs, BArchiv 19, Munich-Leipzig 2000, p. 45-55, and C. MAN-

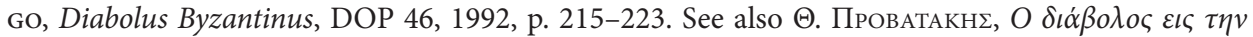

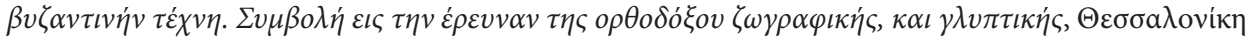
1980; R. Greenfield, Fallen into Outer Darkness: Later Byzantine Conceptions and Depictions of Evil, Efo 5, 1992, p. 61-80. One of the rare writings concerning demonology in Byzantium, the dialogues On the Operation of daemons, has been considered as a work of Michael Psellos (1018-1078 or later), but this authorship has been questioned and the date of the dialogues shifted to the end $13^{\text {th }}$ century, see P. Gautier, Le De daemonibus du Pseudo-Psellos, REB 38, 1980, p. 105-194.

${ }^{7}$ Some of these writings will be referred to further in this text with the related literature; in addition, for the Slavonic apocryphal variants of the stories paralleling the first chapters of Genesis, see А. Яцимирский, Библиографический обзор апокрифов в южнославянской и русской письменности (Списки памятников), fasc. 1. Апокрифы ветхозаветные, Петроград 1921; Стара българска титература. 1. Апокрифи. еd. Д. Петканова, София 1981; Апокрифы Древней Руси: тексты и исследования, еd. В. Мильков, Москва 1997; Apokryfy i legendy starotestamentowe Słowian południowych, ed. G. Minczew, M. SKowroneK, Kraków 2006.

${ }^{8}$ Й. Иванов, Богомилски Книги и тегенди, София 1970; Д. ДИМитрова-МАРИновА, Богомильская космогония в древнеславянской литературной традиции, [in:] От Бытия к Исходу. Отражение библейских сюжетов в славянской и еврейской народной культуре, ed. В. Петрухин et al., Москва 1998, p. 38-58; Y. Stoyanov, Medieval Christian Dualist Perceptions and Conceptions of Biblical Paradise, SCer 3, 2013, p. 149-166; M. Sкоwronek, Remarks on the Anathemas in the Palaea Historica, SCer 3, 2013, p. 131-144.

${ }^{9}$ See G. Minczew, John Chrysostom's Tale on How Michael Vanquished Satanael - a Bogomil Text?, SCer 1, 2011, p. 23-54 and the earlier literature on the topic cited in this study. 
Revelation ${ }^{10}$ and was implied in the works of some of the Church Fathers ${ }^{11}$. Still, the view that protoplasts were deceived by Satan through his interference with the snake prevailed. It is mentioned in homiletic writings, for instance in John Chrysostom's $17^{\text {th }}$ homily on Genesis, in the commentary of the expulsion from Eden: ...the good God, too, have pity on man for the plot to which he fell victim with his wife after being deceived and accepting the devil's advice through the serpent ${ }^{12}$. The episode of Satan's contact with the snake, which enables him to enter Paradise is present with much more details in some apocryphal works, for instance in the Greek and Slavonic versions of the Life of Adam and Eve $e^{13}$, in the Slavonic Apocalypse

\footnotetext{
${ }^{10}$ And the great dragon was cast out, that old serpent, called the Devil, and Satan, which deceiveth the whole world: he was cast out into the earth, and his angels were cast out with him (Rev 12:9).

${ }^{11}$ Justin Martyr (103-165) wrote in his First Apology: the chief of the wicked demons we call the serpent, Satan, the devil... will be cast into the fire of Hell and explained in the Dialogue with Trypho that the Devil had a compound name made up of the actions which he performed; for the word "Sata"... means "apostate", while "nas" is the word which means in translation 'serpent'; thus, from both parts is formed the one word 'Satanas', see Saint Justin Martyr, The first apology, the second apology, dialogue with Trypho, exhortation to the Greeks, discourse to the Greeks, the monarchy, or the rule of God [FC, vol. 6], trans. T. FALls, Washington 1965, p. 64, 310. As a comparison, in the corresponding episodes from the life of the protoplasts in the Koran (Quran) the snake is entirely substituted by Satan, see Koran 7, 20. The differences between Christian and Muslim faith concerning the creation of man and the place of Satan in it were discussed in Byzantium as early as $9^{\text {th }}$ century by Nicetas of Byzantium in his polemic against Islam (The Refutation of the Quran, PG 105, 741A), see A. Khoury, Polémique byzantine contre L'Islam (VIIIe-XIIIe s.), Leiden 1972, p. 147.
}

${ }^{12}$ Saint John Chrysostom, Homilies on Genesis 1-17 [FC, vol. 74], tr. R. Hill, ed. Th. Halton, Washington 1986, p. 222. The association of the Eden serpent with Satan is characteristic for the Armenian Christian sources, where it received considerable elaboration and has different aspects, see M. Stone, 'Be You a Lyre For Me': Identity or Manipulation in Eden, [in:] The Exegetical Encounter between Jews and Christians in Late Antiquity, ed. E. Grypeou, H. Spurling, Leiden 2009, p. 87-99. This connection is likewise attested in midrashic tradition, but its amplification remained limited, see H. Spurling, E. Grypeou, Pirke de-Rabbi Eliezer and Eastern Christian Exegesis, CCO 4, 2007, p. 217-243. According to the authors given the widespread popularity of the idea of the devil using the serpent as an intermediary in Christian sources, it seems likely that Pirke de-Rabbi Eliezer may have incorporated such a tradition through knowledge of the Christian idea.

${ }^{13}$ For the Life of Adam and Eve, which is probably the most popular apocryphal writing on the life of the protoplasts with extant recensions in Greek, Latin, Slavonic, Armenian, Georgian, Coptic, see J. Tromp, The Life of Adam and Eve in Greek: A Critical Edition, Leiden-Boston 2005 (this book remained inaccessible for me); for the Slavonic variants see V. JAGIC, Slavische Beiträge zu den biblischen Apocryphen, I, Die altkirchenslavischen Texte des Adamsbuche, Wien 1893 (=DKAW.PhH 42, p. 1-104); А. Милтенова, Текстологически наблюдения върху два апокрифа: Апокрифен иикбл за крвстното дърво, приписван на Григорий Богослов, и апокрифа за Адам и Ева, СЛ 11, 1982, p. 35-55; Д. ДимитровА, Някои наблюдения вбрху литературните особености на апокриба "Слово за Адам и Ева", 11, 1982, p. 56-66. Here the text from V. JAGIC, op. cit., will be quoted (English translation by S. French, R. LAYTON, G. ANDERSON as published on http://www2.iath.virginia.edu/anderson/vita/english/vita.sla.html\#per18 the website of the project The Life of Adam and Eve: The Biblical Story in Judaism and Christianity, last visited August 31, 2015): Then Eve said, "I will share with you, my children, in what manner our enemy deceived us... Adam watched the 
of Baruch ${ }^{14}$ (3 Baruch), The Sea of Tiberias ${ }^{15}$ or in the Historical Palaea ${ }^{16}$. Although very popular in literature, this Devil-snake relationship did not find its equivalent visualization in Eastern Orthodox art. Indeed there are images of The Fall with special characteristics of the serpent, which are influenced by non-biblical texts, but they are very rare $^{17}$. Such an example we see in three of the illustrated

eastern and northern sides of Paradise... And so the enemy entered in from that side on which Adam was, and he called the serpent to himself and said to it: You are loved by God, therefore she (Eve) will give credence to you before any other creature. And he instructed it in everything and sent it to me. The serpent believed that it was an angel, and came to me. And the devil had changed to the form of an angel and came here with radiance, singing an angel's song, just like an angel, and said to me: 'Do you eat from everything in Paradise?' And at that time I took him for an angel, because he had come from Adam's side, so I said to him, 'From one tree the Lord commanded us not to eat, the one which stands in the middle of Paradise.' The devil said, 'I am very sorry for you, because you don't understand; I alone will tell you so much: That tree is better than all the others. If you tasted from that tree, you would become like gods and radiant like the angels.' And I listened to these words and as I tasted from the tree, immediately my eyes were opened and I saw, that I was naked, and I cried bitterly about what I had done. The devil, however, became invisible".

${ }^{14}$ For Slavonic manuscripts of The Apocalypse of Baruch (3 Baruch), see А. Яцимирский, op. cit., p. 227-232; Стара българска литература. 1..., p. 71-76, 353-354, A. Kuliк, 3 Baruch: GreekSlavonic Apocalypse of Baruch, Berlin 2010. See also F. Badalanova, These Blasphemous Rus-

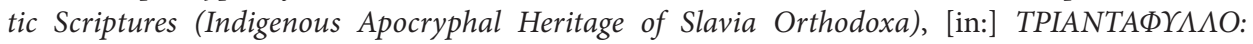
In Honorem Hristo Trendafilov. Юбилеен сборник в чест на 60-годишнината на профб. д.фил.н. Христо Трендабилов, ed. V. РАлауотоv, Шумен 2013, p. 80 and note 117 with the narration of this episode as it is attested in $15^{\text {th }}$ century Russian recension of the Apocalypse of Baruch, here the English translation will be quoted: According to this text, after his having been cast out (on the account of his refusal to obey God's order to bow down to Adam), Sotonail returned to Paradise in the following way: Then having gone, Sotonail [i.e. Satan] found the serpent and he made himself into a worm. And he said to the serpent, "Open [your mouth], consume me into your belly. And he went through the fence into Paradise, wanting to deceive Eve (quoted after: H.E. GAYLORD, How Satanael lost his '-el', JJS 33, 1982, p. 304.

${ }_{15}$ Д. Димитрова, Сказание за Тивериадското море. Текстологично изстедване и критическо издание (SMSB 4), София 2014; see also F. Badalanova, These Blasphemous Rustic Scriptures..., p. 66-106, esp. p. 90 with an edition and English translation of the text which is part of the $18^{\text {th }}$ century Miscellany (N 448, former N 56) from the Grigorovich's collection at Odessa State Scientific Library: and Satan envied Adam, who reigned in Paradise living in perfection... And Satan curled himself around the grapevine and began to speak to Eve with the lips of a serpent: "Why don't you taste of this grapevine? You will become gods like the Heavenly God".

${ }_{16}$ А. Попов, Книга Бъттия небеси и земли: Палея историческая с приложением сокращенной Палеи Русской редакиии, ЧИОИДР 1, 1881, 3-4.

${ }^{17}$ A different situation is observed in Western art. From the $13^{\text {th }}$ century onward in the scene of The Fall a new motif appeared, the woman-headed serpent. The majority of the scholars who dealt with this novelty agree that it is influenced by the text of Peter Comestor's Historia Scholastica, composed in the middle of the $12^{\text {th }}$ century, namely, the Comestor's commentary on Genesis 3:1, which states that in order to deceive Eve the Devil used a serpent with a woman's face thus gaining Eve's confidence, because one accepts more easily what is similar to oneself:... He [Satan] also chose a certain kind of serpent, as Bede says that had the countenance of a virgin because 'similia similibis applaudunt', see J. BonneL, The Serpent with a Human Head in Art and in Mystery Play, AJA 21, 3, 
Byzantine Octateuchs from the $12^{\text {th }}$ century: in MS gr. 8 (Istanbul, Topkapi Sarayi Library, ca. 1125-1155); MS Vat. Gr. 746 (Rome, Biblioteca Apostolica Vaticana, ca. 1125-1155) and Smyrna Octateuch (Cod. A1, once in the Library of the Evangelical School of Smyrna, not extant today). In these manuscripts in the scene of the Temptation of Eve the snake is represented in conjunction with a camel ${ }^{18}$. This peculiar image was much discussed in the literature ${ }^{19}$ and Kurt Wetzmann ${ }^{20}$ was the first to point out its connection to an account in the explanatory Jewish texts, according to which Satan, having chosen the serpent for his purposes, descended from heaven and saddled the snake as if he was saddling a camel; then the snake became possessed by his spirit, henceforth everything it spoke was affected by Satan ${ }^{21}$.

1917, p. 255-291; H. Kelly, The Metamorphoses of the Eden Serpent During the Middle Ages and Renaissance, V 2, 1971, p. 301-328; for the occurrence and meaning of this motif in Jewish art see S. Laderman, Two Faces of Eve: Polemics and Controversies Viewed Through Pictorial Motifs, Ima 2, 2008, p. 1-20. The woman-headed serpent occurred in a much later period in the Eastern Orthodox variants of The Fall, no doubt under Western influence, but it seems that Eastern icon painters simply borrowed the model without any notion of its meaning.

${ }^{18}$ M. BERnABò, Searching for Lost Sourses of the Illustration of the Septuagint, [in:] Byzantine East, Latin West. Art Historical Studies in Honor of K.Weitzmann, Princeton 1995, p. 333, fig. 4; K. Weitzmann, M. Bernabò, R. Tarasconi, The Byzantine Octateuchs, 1: Text; 2: Plates (Illustrations in the Manuscripts of the Septuagint, 2.), Princeton 1999, p. 33-34; J. Lowden, Illustrated Octateuch Manuscripts: A Byzantine Phenomenon, [in:] The Old Testament in Byzantium, eds. P. Magdalino, R. NeLson, Washington, D.C. 2010, p. 126-129, 143; M. BERnabò, The Illustration of the Septuagint: The State of the Question, MJBK, series 3, t. 63, 2012, p. 37-68.

${ }^{19}$ See the bibliography in K. Weitzmann, M. Bernabò, R. Tarasconi, op. cit., p. 33-34.

${ }^{20} \mathrm{~K}$. Weitzmann, The Illustration of the Septuagint, [in:] Studies in Classical and Byzantine Manuscript Illumination, ed. H. KessLer, Chicago 1971, p. 48.

${ }^{21}$ The corresponding text is in the chapter 13 of Pirke de-Rabbi Eliezer: Sammael was the great prince, who was in heaven [...] He [...] descended and saw all the creatures which the Holy One, Blessed be He, had created, and he found none so clever to do evil as the serpent [...] Its likeness was like a kind of camel, and he mounted and rode upon it [...] Thus it was with the serpent. All the deeds which it did, and all the words which it spoke, it did not speak and it did not do except by the intention of Sammael. The text is quoted from The Book of Genesis in Late Antiquity: Encounters Between Jewish and Christian Exegesis, ed. E. Grypeou, H. Spurling, Leiden 2013, p. 48. The possible source of the camel-like image of the snake in the above-mentioned Byzantine Octateuchs is still under discussion: another eminent scholar in the field, Massimo Bernabò, suggested as more plausible the connection with Hebrew Genesis Rabbah, see K. Weitzmann, M. Bernabò, R. Tarasconi, op. cit., p. 33-34; or with a tale close to The Cave of Treasures, see M. BERnABò, op. cit., p. 51-52. Both Weitzmann's and Bernabò's opinions were questioned by John Lowden, who is more inclined to search for influences from contemporary to the Octateuchs discussions echoed in Constantinopolitan chronicles, which described the serpent as having feet (Chronicle of Zonaras), or specifically mentioned it not to have had feet (Chronicle of Kedrenos), see J. LowDEN, op. cit., p. 126-127. All these debates appeared in the context of the polemic on the common model for the illustrated Octateuchs and though the problem of the possible literary source for the camel-like quadruped image of the serpent was of importance for this polemic, it remained somehow peripheral for the researchers and still needs more attention. 
Aside from this interesting example, Orthodox art does not display explicitly the role of the Devil in the temptation episode ${ }^{22}$.

We should note that in general Satan's image in Byzantine and Orthodox art has a variety of disguises, but some of its features remained unchanged for a long period. Two main types of Devil images are distinguished by the researchers. The first is the so-called 'eidolon' (gr. $\varepsilon$ " $\delta \omega \lambda$ ov 'double, apparition, phantom, ghost'), which is a winged naked figure in a gray or darker color with hair sticking up, while the second is again an anthropomorphic figure, often without wings, similar to the ancient Pan or satyr ${ }^{23}$. Exactly in this second variant the Devil is rendered in scenes that represent him deceiving Adam to sign a contract. The pact between Satan and Adam is another story which acquired great popularity in Slavia Orthodoxa through several apocrypha, among them the Slavic version of The Life of Adam and $E_{v e} e^{24}$ and The Sea of Tiberias ${ }^{25}$. Adam wrote this contract in exchange for the right to work the land, or in exchange for the return of the light, according to

\footnotetext{
${ }^{22}$ On the other hand, The Slavonic Apocalypse of Baruch and The Sea of Tiberias include another episode of Satan's interference - the Second Temptation of Eve, which equally was practically not visualized in Orthodox art. One of the rare exclusions is the existence of a miniature on the subject in the $16^{\text {th }}$ century illustrated manuscript of Georgios Choumnos - Metrical Paraphrase of Genesis and Exodus, Add MS 40724, where the scene probably appears under Western influence. In the Western art there are images of the Second temptation, as well as the image of the Devil as a bright angel in The Temptation and The Fall.

${ }^{23}$ Sее Д. Антонов, М. МАйзульс, Демоны, монстры и грешники в пространстве древнерусской иконограбии, Оди 2010/2011, p. 144-198 and the literature quoted in this study.

${ }^{24}$ The text in the Slavonic Life of Adam and Eve is quoted here after English translation made by S. French, R. Layton, G. Anderson as published on the website of the project The Life of Adam and Eve: The Biblical Story in Judaism and Christianity, http://www2.iath.virginia.edu/anderson/vita/ english/vita.sla.html\#per3 (last visited August 31, 2015): Accordingly, Adam took oxen and began to till, that he might obtain nourishment. Then the devil appeared and stood steadfastly in front of the oxen and wouldn't allow Adam to till the earth, and the devil said to Adam, 'the earth is mine, God owns Heaven (and Paradise). If you want to become mine, then, by all means, till the earth. If, however, you want to belong to God then go only into Paradise'. Adam said, 'God owns Heaven and Paradise, but God also owns the earth and the sea and the entire world. The devil said, 'I will not permit you to till the earth, unless you sign a cheirograph (contract), pledging that you belong to me'. Adam said, 'Whoever is Lord of the earth, to him both I and my children belong. Adam knew of course that the Lord would come down to the earth and take on himself the form of a man and trample down the devil. The devil was, nevertheless, extremely pleased and said, 'Write for me your cheirograph'. And Adam wrote and said, 'Whoever is Lord of the earth, both I and my children belong to him'.

${ }^{25}$ Here I will quote the English translation according to F. Badalanova, op. cit., p. 91: And Adam, together with his wife, began mourning and weeping on account of being cast out of Paradise; the Lord wanted to pardon him, having seen his pure repentance from the heart and sighs and tears on his face [and prayers]: "Most merciful ruler, you who know all fates, save the fine Adam!" And Satan heard Adam's mourning and his lamenting on account of the sin, and because the Devil had been cunning and hateful from the very beginning, he came to Adam and said to him, "I will give you good tidings. The Lord is willing to pardon you. Give me a writ for yourself and your kin. As for you, Eve, swear an oath to me".
} 
a parallel version of this story ${ }^{26}$. The extant images that visualize this apocryphal tale are known mainly from fresco cycles with the story of Adam, Eve, Cain and Abel on the facades of several churches in northeastern Romania depicted in the $16^{\text {th }}$ century ${ }^{27}$.

The present study is focused on another example - the inclusion of the image of the Devil behind Cain's figure in a number of depictions of the scene The Murder of Abel in the Russian art of the $16^{\text {th }}$ and $17^{\text {th }}$ centuries. It seems that the earliest example of this motif appears on the famous quadripartite icon from the Annunciation Cathedral of the Moscow Kremlin (Moscow, 1547-1551) ${ }^{28}$ and then in later icons affected by this iconography ${ }^{29}$. The same motif is extant in The Murder

\footnotetext{
${ }^{26}$ In early publications on the problem of the origin of the plot, its existence and spread, particularly in the Slavic version of The Life of Adam and Eve, is explained by the influence of Bogomilism - a heretical doctrine with dualistic basis and serious impact in the history of Orthodoxy, see V. JAGIC, op. cit., p. 41-49; Й. ИвАнов, Богомилски книги и легенди, p. 215, 223-227. Later, Emil Turdeanu criticized this idea, arguing that not always, when it comes to a dualistic concept of the world, the relation to Bogomilism is justified and provable, see É. TuRdEAnU, Apocryphes bogomiles et apocryphes pseudo-bogomiles, [in:] IDEM, Apocryphes slaves et roumains de l'Ancien Testament [SVTP, 5], Leiden 1981, p. 17-31 (1-74). On the other hand, Alexander Naumov drew attention to liturgical texts as a possible source for the motif of Adam's contract, see A. NAumow, Apokryfy w systemie literatury cerkiewno-słowianskiej, Wrocław-Warszawa- Kraków 1976. The textual and visual tradition associated with this motif has been reviewed in the last study of Michael Stone, see M. STONE, Adam's Contract with Satan: The Legend of the Cheirograph of Adam, Indiana University Press 2002.

${ }^{27}$ This composition is depicted on the western façade of the catholicon of the Moldovita Monastery (1532), on the north façade of the catholicon of the Voronet Monastery (1547) and on the north façade of the catholicon of the Sucevita Monastery (1596); some of the images were published in P. Henry, Les eglises de la Moldavie du Nord des origines a la fin du XVIe siecle. Architecture et peinture, Paris 1930.

${ }^{28}$ The upper left field, named "И почи Бог в день седьмыи" (“And God rested on the seventh day") represents scenes from the story of Adam, Eve, Cain and Abel, among them The Murder of Abel, where the Devil is represented behind Cain, see И. КАчАловА, Н. МАясовА, л. ЩенниковА, Благовещенский собор Московского Кремля: К 500-летию уникального памятника русской культуры, Москва 1990, p. 61-64, ill. 178. This example is discussed in: Н. КвливидзЕ, Сотворение мира и история Адама и Евы в росписи Успенского собора Свияжского монастыря: к проблеме интерпретации сакрального пространства в русском искусстве XVI в., [in:] Древнерусское искусство. Идея и образ. Опыты изучения византийского и древнерусского искусства, Москва 2009, р. 343-366; Д. Антонов, М. МАйзульс, Анатомия ада: Путеводитель по древнерусской визуальной демонологии, Москва 2014, р. 52.

${ }^{29}$ Among these examples are: the icon with the composition "И почи Бог в день седьмый" ("And God rested on the seventh day"), $17^{\text {th }}$ century, today in the Church Historical and Archeological Museum in the Ipatiev Monastery, Kostroma, Russia, see Н. Комашко, С. КАтКовА, Костромская икона XII-XIX веков: Свод русской иконописи, Москва 2004; the icon Creation of the world with saints from the collection of the Tretyakov State Gallery in Moscow, Stroganov school, end $16^{\text {th }}$ - beginning $17^{\text {th }}$ century, see София. Премудрость Божия. Каталог выставки русской иконописи XIII-XIX веков из собраний музеев России, Москва 2000, № 61, p. 184-185; an icon, part of the south doors of the iconostasis of St. Nicholas Monastery, Pereslavl-Zalessky, Russia, end $17^{\text {th }}$ century, Inv. № П3М-368, ЖТ-2.
} 
of Abel from the lavishly illustrated Chronicle of Ivan the Terrible (Лицевой летописный свод) dating from the late ' 60 s of the $16^{\text {th }}$ century ${ }^{30}$. It can be seen also in the church murals, for example in the Dormition cathedral of Svijazhsk monastery $^{31}$, in the Church of the Resurrection of Christ in Kostroma (1650-52) ${ }^{32}$, or the Church of Resurrection in Tutaev (1680). The existence of these images raises several questions: what is the literary context of the relationship Cain-Devil, is there any earlier tradition of visualizing this motif and why he received a higher prevalence in Russian painting.

In literature, the connection between Cain and Satan was made early: the New Testament speaks of the devil as a sinner, a liar, and a murderer from the beginning, and of Cain and other sinners as children of the Devil (In. 8, 44; 1 In. 3,8-12). Several of the Church Fathers in their homiletic writings share the opinion that Satan deceived Cain and caused him to kill Abel, among them Basil of Seleucia, John Chrysostom, Isaac of Antioch ${ }^{33}$.

As far as images are concerned, it should be noted that there are earlier examples of the inclusion of the Devil in The Murder of Abel of Western provenance: in French illuminated manuscripts and stained glass, dating back to $13^{\text {th }}-15^{\text {th }}$ century $^{34}$. There is no obvious connection between these Western images and the Russian ones. In addition, the art of the Byzantine period did not include this iconography. Basically, the Creation of the world and the story of Adam and Eve, Cain and Abel were rarely illustrated in Byzantium ${ }^{35}$, a relatively larger number of examples

\footnotetext{
${ }^{30}$ Н. КвливидзЕ, op. cit., p. 362.

${ }^{31} \mathrm{Ibidem}$. The Creation cycle in the Dormition cathedral of Svijazhsk monastery has been considered as the earliest example among the extant today late medieval Russian fresco ensembles, having been dated by the majority of Russian scholars to 1560s. This opinion has been questioned lately by Aleksandr Preobrazhensky with sustainable arguments for a later execution date of this fresco program - early $17^{\text {th }}$ c., see A. ПреобрАЖенскиЙ, О стиле и времени создания росписи собора Успенского монастыря в Свияжске, [in:] Лазаревские чтения. Искусство Византии, Древней Руси, Западной Европы, Москва 2009, p. 268-308.

${ }_{32}$ А. Кильдышев, Фрески иеркви Воскресения на Дебре в Костроме, Кострома 1996.

${ }^{33}$ J. GlenthøJ, Cain and Abel in Syriac and Greek writers ( $4^{\text {th }}-6^{\text {th }}$ centuries), Louvain 1997, p. 147, p. 279-281. Basil the Great in his Sermon on Envy, wrote that the Devil is sly and contributes to falling in all sins, one of the most devastating of which is envy; the Devil himself, in his envy, sought revenge on Adam because of God's gifts to him, and because he could not exact revenge on God himself, and Cain did the same as the first disciple of the devil, learned from him envy and murder, sее Творения иже во святых отиз нашего Василия Великого архиеп. Кесарии Каппадокийской, t. 1-3, Санкт-Петербург 1911, t. 2, p. 162-176.

${ }^{34}$ See, for example, the miniature of The Murder of Abel from the illustrated Bible Mazarine (ms. 0036, f. 6) from the $12^{\text {th }}$ century, represented in the CNRS database ENLUMINURES, available online: http://www.enluminures.culture.fr/documentation/enlumine/fr/presentation_00.htm, last visit 30 August 2015; or the miniature of the Murder of Abel in the lavishly illustrated Book of Hours of Jean de Montauban, Bretagne ca. 1450 (Rennes, Bibliothèque municipale, ms. 1834).

${ }^{35}$ For the Genesis cycle in Byzantine art, in addition to the literature on the illustrated Byzantine Octateuchs mentioned above, see A. EAstmond, Narratives of the Fall: Structure and Meaning in the
} 
are preserved in the Orthodox art of $16^{\text {th }}-17^{\text {th }}$ century. A variety of cycles are known today, including those in the churches Arbore (1541), Voroneţ (1547), Moldoviţa (1532), Suceviţa (1596) $)^{36}$ in northeastern Romania; the cycle in St. Nicholas church of the Philanthropinon monastery (1560) at Ioannina, Greece ${ }^{37}$; the cycles in the refectory of the Great Lavra (third quarter of the $16^{\text {th }}$ century) $)^{38}$, in the narthex of the monastery Docheiariou, also on Mount Athos (1568) $)^{39}$, as well as several examples from $17^{\text {th }}$ and $18^{\text {th }}$ centuries ${ }^{40}$. Although some of them end with the story of Cain and Abel, in no case was the figure of the Devil represented behind Cain. As we see, the earliest images are Russian, and they are numerous.

Here I will give only some preliminary notes on the possible reasons for the occurrence of this motif precisely on Russian soil. The phrase: 'and Satan entered into Cain and incited him to kill Abel' ('и сотона влезе в каина и пострекаше убити авеля... и рече сатана: вземеши камень, удари Авеля и уби его') is actually a prevalent element that is transmitted with minor variations in different texts, which were popular in $16^{\text {th }}-17^{\text {th }}$ century Russia. We find the motif much earlier, for example in the some of the recensions of the Short and the Explanatory Palaea ${ }^{41}$, and as early as $12^{\text {th }}$ century in the text of the Old Russian Tale of Bygone Years (Povest' vremennykh let or Primary Chronicle) $)^{42}$. At the same early stage the motif

Genesis Frieze at Hagia Sophia, Trebizond, DOP 53, 1999, p. 219-236; J. МАрковић, М. МАрковић, Циклус Генезе и старозаветни фигуре у параклису св. Димитрија, [in:] Зидно сликарство Дечана. Граћа и студије, Београд 1995, p. 324- 330.

36 P. Henry, op. cit.; A. VAsiliu, Monastères de Moldavie, XIVe-XVIe siècles: Les architectures de l'image, Paris 1998, p. 201-205; G. HereA, Mesajul eshatologic al spaţiului liturgic creștin: arhitectură și icoană în Moldova secolelor XV-XVI, Suceava 2013, p. 148, 163, fig. 73, 74, 190-195, 302. See also M. Kuyumdzhieva, Creation of the World and Adam and Eve in Post-Byzantine Art: Some Notes on Genesis Cycles in Arbore and Suceviţa, APu XI, 1, 2015, p. 233-248.

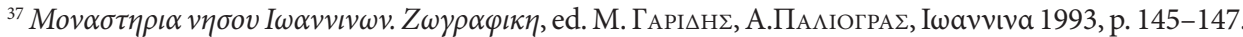
${ }^{38}$ J. Yiannias, The Refectory paintings of Mouth Athos: An Interpretation, [in:] The Byzantine Tradition after the Fall of Constantinople, ed. IDEM, Charlottesville-London 1991, p. 269-340, 290.

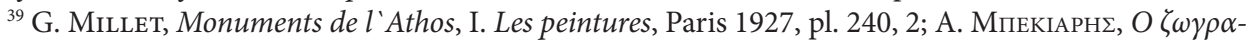

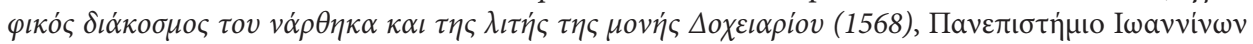
2012, p. 325-338.

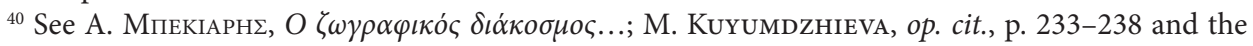
earlier literature cited there. For several examples in manuscripts and on icons which survived on the territory of Bulgaria see Е. МусаковА, Надписи и изображения Шестоднева в болгарских рукописях и иерковной живописи XVII-XIX вв, [in:] От Бытия к Исходу. Отражение библейских сюжетов в славянской и еврейской народной культуре, ed. В. Петрухин et al., Москва 1998, p. $118-129$.

${ }^{41}$ Палея Толковая по списку сделанному в Коломне 1406 г., Москва 1892, Стлб. 190. Same detail occurred in the corresponding text of the Rumiantsev's Palaea from 1494, Ms. № 453, see А. Пыпин, Памятники старинной русской литературы, издаваемые Грабом Григорием Кушелевымъ-Безбородко. Выпуск третій. Ложныя и отреченныя книги русской старины, собранныя А.Н. Пьпинымъ, Санкт-Петербург 1862, р. 9.

${ }^{42}$ The motif here occurs in the speech of the Christian Philosopher before Vladimir, which retells the biblical story. There is a hypothesis that this part of the Tale of Bygone Years together with the 
Cain-Satan was reinterpreted in Russian hagiographical literature dedicated to Sts. Boris and Gleb ${ }^{43}$. The Devil's influence upon Cain is mentioned also in some Russian recensions of the apocryphon The Sea of Tiberias ${ }^{44}$, and of the apocryphal Revelation of Pseudo-Methodius of Patara ${ }^{45}$. This great intensity in the literary field shows that the motif of Satan's influence on Cain in the episode of the murder of Abel has almost turned into a topic. Hence, its emergence in Russian milieu, and more specifically in the icon from the Annunciation Cathedral of the Moscow Kremlin (Moscow, 1547-1551) as earliest case in point, becomes more explicable.

In the $17^{\text {th }}$ century the image of the Devil behind Cain's figure appeared also in the frescoes of the Nativity Church in Arbanassi village, Bulgaria, where the scene of The Murder of Abel is part of the iconographical program of the eastern end of the gallery painted in $1643^{46}$. These murals are a work of icon painters of Greek provenance or education; all the inscriptions in the church are in Greek. The other known to me Greek examples of The Murder of Abel do not include the figure of the Devil $^{47}$. The existence of this motif in Arbanassi murals is most likely connected to

corresponding parts from the Explanatory Palaea have a common source - a variant of Slavic Chronograph, see А. ШахмАтов, Повесть временных лет и ее источники, ТОДЛ 4, 1940, р. 6-151, 139; С. Михеев, Кто писал «Повесть временных лет»?, Москва 2011.

${ }^{43}$ The Kievan Princes Boris and Gleb were killed during a revolt following Vladimir's death in 1015 by their stepbrother Sviatopolk. Not surprisingly, because of his fratricide Sviatopolk was compared to Cain and described as a tool of the Devil's plot in the saints' vitae (Сказание о Борисе и Глебе, Чтение о житии и о погублении блаженных страстотерпиев Бориса и Глеба), seе Б. Успенский, Борис и Глеб: восприятие истории в древней Руси, Москва 2000.

${ }^{44}$ See the Barsov's edition of the text from the $16^{\text {th }}$ century manuscript (N 2486, ГИМ): Е. БАРСОВ, О Тивериадском море, ЧИОИДР 2, 1886, p. 5-8, and an $18^{\text {th }}$ century variant published in Д. ДимитровА-МАриновА, Богомильская космогония..., р. 55.

${ }^{45}$ The motif of the Devil's interference on Cain ("Каин же послуша прелести Диаволи") is a late Slavic interpolation in the Revelation of Pseudo-Methodius of Patara; it is absent from the Greek original, in the first Slavic translation (Mount Athos Monastery of Chilandar, Ms. 24, f. 70-77), as well as in the second recension, but is present in the interpolated redaction, known from a $16^{\text {th }}-17^{\text {th }}$ century manuscript, see В. Истрин, Откровеніе Мефодия Патарскаго и апокрифическия Видения Даниила в византийской и славяно-русской литературах: исследованіе и тексты, Москва 1897. ${ }^{46}$ л. ПрАшков, Църквата "Рождество Христово" в Арбанаси, София 1979.

${ }^{47}$ These examples are numerous and here only two will be quoted: The Murder of Abel, part of the Genesis cycle from the gallery of the catholicon of the Monastery St. Nicholas Philanthropinon (1560),

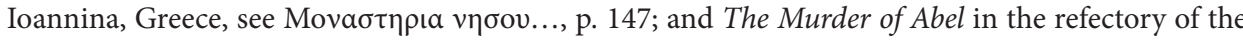
Great Lavra (third quarter of the $16^{\text {th }}$ century), Mount Athos, see G. Millet, Monuments de l'Athos. 1: Les peintures, Paris 1927. In this context it is worth to note that Dionysius of Fourna in his Painter's manual (Hermeneia), while describing how to depict The Murder of Abel, did not mention any presence of the Devil in the composition, the only important detail clarified in his prescription is the tool of the murder - a staff, see П. Успенский, Ерминия или наставление в живописном искусстве, составленное иеромонахом и живописием Дионисием Фурноаграфиотом. 1701-1733 год, Киев 1868 [= ТКДА 1868, t. 1, 2, 4]. Regarding the object which was used in the murder, in the written sources, hence in the imagery, there are several variants - a staff, a stone, a club or other agricultural instrument, a jaw-bone, etc., see M. Shapiro, Cain's Jaw-Bone that did the First Murder, ArtB 24, 
the influence of Russian painting on Balkan art, which is enhanced from $16^{\text {th }}$ century onward ${ }^{48}$. In support of this suggestion comes the fact that the program of the same church includes another typically Russian iconographic model, also known by the four-partite icon from the Annunciation Cathedral - a specific version of St. Trinity ${ }^{49}$. The model of The Murder of Abel, which depicted the Devil behind Cain, lasted until the $19^{\text {th }}$ century, as we see by the frescoes of the Rila Monastery and St. Nicholas church in Raduil village near Samokov, Bulgaria. The compositions there were again influenced by Russian variants, this time probably deriving from illustrated Synodicons ${ }^{50}$ or folk Bibles, for example the Bible of Vasilyi Koren' (1692-96) where the corresponding scene has a lot of captures, and although none of them mentions the Devil, he is still represented behind Cain ${ }^{51}$.

Taking into account the visual sources it seems that for Eastern orthodoxy Satan's figure occupies a marginal position in relation to the events of the Creation of the world and the life of the protoplasts. This irrelevance recalls in mind Simon Franklin's words from his article on the Russian Literary Demonism and the Orthodox tradition: ... when all is said and done, or tried and tempted, the Devil is a loser. He has no hold over the future; he can act only where God permits and where man loses vigilance; he can be resisted and expelled ${ }^{52}$. On the other hand, all these visual examples illustrate the idea that indeed the text determines the appearance of images in Christianity: the subjects on the icons, frescoes and in the illustrated books are stories from written sources. Furthermore, sometimes images help understand certain processes in literature; they can reveal how texts were interpreted by learned men and, correspondingly, the perception and understanding of these texts by icon-painters and illiterate believers. For this reason, for medievalists, texts and images were long ago proved equally valuable.

1942, p. 205-212. According to Shapiro's conclusion the jaw-bone as Cain's instrument recalls to us that in English, as in older Christian and Jewish tradition, Cain was seen as the son of the devil.

${ }^{48}$ A. Grabar, L'expansion de la peinture russe aux XVIe et XVIIe siècles, [in:] L'art à la fin de l'antiquité et du Moyen Âge, II, Paris 1968, p. 939-963; M. SABADos, Influences occidentales dans la peinture roumaine d'icône du XVIIe siècle, RRHA.BA 40, 2002-2003, p. 33, 36-37; I. IANCovescu, Les sources russes et ukrainiennes de la peinture au temps de Constantin Brancovan, RRHA.BA 45, 2008, p. 101-116.

${ }^{49}$ М. КуюмджиевА, Изображението на Св. Троица в наоса на иърквата „Рождество Христово" в Арбанаси - иконограбски прототипи и съдържание, СЛ 43-44, 2010, p. 209-235.

${ }^{50}$ See the illustration №5 in: Д. Антонов, М. МАйзульс, Анатомия ада..., p. 55. For the illustrated Synodicons in Bulgaria and their influence on Bulgarian art from the National Revival period see И. ГерговА, Духовни образи. Руски илюстриран синодик, София 2014.

${ }^{51}$ Библия Василия Кореня. 1692-1696, Москва 1983, р. 18; А. САКович, Народная гравированная книга Василия Кореня, Москва 1983, р. 37.

${ }^{52}$ See S. Franklin, Nostalgia for Hell: Russian Literary Demonism and Orthodox Tradition, [in:] Russian Literature and its Demons, ed. P. DAvidson, New York-Oxford 2000, p. 31-58. 


\section{Bibliography}

Apokryfy i legendy starotestamentowe Słowian południowych, ed. G. Minczew, M. SKowroneK, Kraków 2006.

Badalanova F., These Blasphemous Rustic Scriptures (Indigenous Apocryphal Heritage of Slavia

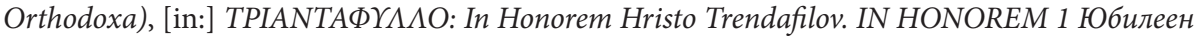
сборник в чест на 60-годишнината на профб. д.фил.н. Христо Трендафилов, еd. V. РAnауотоv, Шумен 2013, p. 66-106.

Bakalova E., Principles of Visualization of the Pseudo-Canonical Texts in the Art of the Byzantine Commonwealth, [in:] Biblia Slavorum Apocryphorum II. Novum Testamentum, ed. G. Minczew, M. SkowroneK, I. Petrov, Łódź 2009, p. 167-189.

Bernabò M., Searching for Lost Sources of the Illustration of the Septuagint, [in:] Byzantine East, Latin West. Art Historical Studies in Honor of K. Weitzmann, Princeton 1995.

Bernabò M., The Illustration of the Septuagint: The State of the Question, MJBK, series 3, t. 63, 2012, p. 37-68.

Biblia Slavorum Apocryphorum I. Vetus Testamentum [FE, 4, fasc. VI/VII], Gniezno 2007.

Biblia Slavorum Apocryphorum II. Novum Testamentum. Materiaty z Międzynarodowej Konferencji Naukowej „Biblia Slavorum Apocryphorum. II. Novum Testamentum” Łódź, 15-17 maja 2009 r., ed. G. Minczew, M. Skowronek, I. Petrov, Łódź 2009.

Bonnel J., The Serpent with a Human Head in Art and in Mystery Play, AJA 21, 3, 1917, p. 255-291.

Cartlidge D., J. Elliott, Art and the Christian Apocrypha, London 2001.

CNRS database ENLUMINURES, available online: http://www.enluminures.culture.fr/documentation/enlumine/fr/presentation_00.htm, last visit 30 August 2015.

Ducellier A., Le Diable à Byzance, [in:] Le diable au Moyen Âge: Doctrine, problèmes moraux, représentations. Nouvelle édition, Aix-en-Provence 1979, p. 195-212 (http://books.openedition.org/ pup/2636).

Eastmond A., Narratives of the Fall: Structure and Meaning in the Genesis Frieze at Hagia Sophia, Trebizond, DOP 53, 1999, p. 219-236.

Franklin S., Nostalgia for Hell: Russian Literary Demonism and Orthodox Tradition, [in:] Russian Literature and its Demons, ed. P. DAvidson, New York-Oxford 2000, p. 31-58.

GAYLORD H.E., How Satanael lost his '-el', JJS 33, 1982, p. 303-309.

Gautier P., Le De daemonibus du Pseudo-Psellos, REB 38, 1980, p. 105-194.

Glenthøj J., Cain and Abel in Syriac and Greek writers (4 ${ }^{\text {th }}-6^{\text {th }}$ centuries), Louvain 1997.

Gokey F., The Terminology for the Devil and Evil Spirits in the Apostolic Fathers, Washington 1961.

Grabar A., L'expansion de la peinture russe aux XVIe et XVIIe siècles, [in:] L'art à la fin de l'antiquité et du Moyen Âge, II, Paris 1968, p. 939-963.

Greenfield R., Fallen into Outer Darkness: Later Byzantine Conceptions and Depictions of Evil, Efo 5, 1992, p. 61-80.

Guillou A., Le diable byzantin, [in:] Polyplevros Nous. Miscellanea für Peter Schreiner zu seinem 60. Geburtstag, ed. C. Scholz, G. MaKris, BArchiv 19, Munich-Leipzig 2000, p. 45-55.

Henry P., Les eglises de la Moldavie du Nord des origines a la fin du XVIe siecle. Architecture et peinture, Paris 1930. 
IANCOVESCU I., Les sources russes et ukrainiennes de la peinture au temps de Constantin Brancovan, RRHA.BA 45, 2008, p. 101-116.

JAGIC V., Slavische Beiträge zu den biblischen Apocryphen, I. Die altkirchenslavischen Texte des Adamsbuche, Wien 1893 [=DKAW.PhH 42, p. 1-104].

Kelly H., The Metamorphoses of the Eden Serpent During the Middle Ages and Renaissance, V 2, 1971, p. 301-328.

Khoury A., Polémique byzantine contre L'Islam (VIIIe-XIIIe s.), Leiden 1972.

Kulik A., 3 Baruch: Greek-Slavonic Apocalypse of Baruch, Berlin 2010.

Kuyumdzhieva M., Creation of the World and Adam and Eve in Post-Byzantine Art: Some Notes on Genesis Cycles in Arbore and Suceviţa, APu XI, 1, 2015, p. 233-248.

Laderman S., Two Faces of Eve: Polemics and Controversies Viewed Through Pictorial Motifs, Ima 2, 2008, p. 1-20.

Lafontaine-Dosogne J., Iconography of the Cycle of the Infancy of Christ, [in:] The Kariye Djami, IV. Studies in the Art of the Kariye Djami and its Intellectual Background, ed. P. Underwood, Princeton 1975, p. 195-241.

Lafontaine-Dosogne J., Iconography of the Cycle of the Life of the Virgin, [in:] The Kariye Djami, IV. Studies in the Art of the Kariye Djami and its Intellectual Background, ed. P. Underwood, Princeton 1975, p. 161-194.

Life of Adam and Eve, transl. by S. French, R. Layton, G. Anderson as published on the website of the project The Life of Adam and Eve: The Biblical Story in Judaism and Christianity, http://www2.iath.virginia.edu/anderson/vita/english/vita.sla.html\#per3 (last visited August 31, 2015).

Lowden J., Illustrated Octateuch Manuscripts: A Byzantine Phenomenon, [in:] The Old Testament in Byzantium, eds. P. Magdalino, R. Nelson, Washington, D.C. 2010, p. 126-129, 143.

Mango C., Diabolus Byzantinus, DOP 46, 1992, p. 215-223.

Millet G., Monuments de l'Athos. 1: Les peintures, Paris 1927.

Miltenova A., Parabiblical (paratextual) literature in Mediterranean World and its Reception in Medieval Bulgaria (10 th $14^{\text {th }} \mathrm{cc}$ ), [in:] Biblia Slavorum Apocryphorum I. Vetus Testamentum. [FE, 4, fasc. VI/VII], Gniezno 2007, p. 9-20.

Minczew G., John Chrysostom's Tale on How Michael Vanquished Satanael - a Bogomil Text?, SCer 1, 2011, p. 23-54.

Naumow A., Apokryfy w systemie literatury cerkiewno-słowiańskiej, Wrocław-Warszawa- Kraków 1976.

Russell J., Satan: The Early Christian Tradition, New York 1987.

SABADos M., Influences occidentales dans la peinture roumaine d'icône du XVIIe siècle, RRHA.BA 40, 2002-2003.

Saint John Chrysostom, Homilies on Genesis 1-17 [FC, vol. 74], trans. R. Hill, ed. Th. Halton, Washington 1986.

Saint Justin Martyr, The first apology, the second apology, dialogue with Trypho, exhortation to the Greeks, discourse to the Greeks, the monarchy, or the rule of God [FC 6], trans. T. FALLs, Washington 1965.

Shapiro M., Cain's Jaw-Bone that did the First Murder, ArtB 24, 1942, p. 205-212.

Skowroner M., Remarks on the Anathemas in the Palaea Historica, SCer 3, 2013, p. 131-144. 
Spurling H., E. Grypeou, Pirke de-Rabbi Eliezer and Eastern Christian Exegesis, CCO 4, 2007, p. 217-243.

STICHel R., Außerkanonische Elemente in byzantinischen Illustrationen des Alten Testaments, RQ 69, 1974, p. 159-181.

Stone M., 'Be You a Lyre For Me': Identity or Manipulation in Eden, [in:] The Exegetical Encounter between Jews and Christians in Late Antiquity, ed. E. Grypeou, H. Spurling, Leiden 2009, p. 87-99.

Stone M., Adam's Contract with Satan: The Legend of the Cheirograph of Adam, Indiana University Press 2002.

Stoyanov Y., Medieval Christian Dualist Perceptions and Conceptions of Biblical Paradise, SCer 3, 2013, p. 149-166.

The Book of Genesis in Late Antiquity: Encounters Between Jewish and Christian Exegesis, ed. E. GrYPEOU, H. SPURLING, Leiden 2013.

Thiery N., Lillustration des apocryphes dans les églises de Cappadoce, Apocr 2, 1991, p. 217-248.

Tromp J., The Life of Adam and Eve in Greek: A Critical Edition, Leiden-Boston 2005.

TuRdeanu É., Apocryphes bogomiles et apocryphes pseudo-bogomiles, [in:] IDEM, Apocryphes slaves et roumains de l'Ancien Testament [SVTP 5], Leiden 1981, p. 17-31 (1-74).

Vasiliu A., Monastères de Moldavie, XIVe-XVIe siècles: Les architectures de l'image, Paris 1998, p. 201-205.

Weitzmann K., M. Bernabò, R. Tarasconi, The Byzantine Octateuchs, 1: Text; 2: Plates. (Illustrations in the Manuscripts of the Septuagint, 2), Princeton 1999.

Weitzmann K., The Illustration of the Septuagint, [in:] Studies in Classical and Byzantine Manuscript Illumination, ed. H. KessLer, Chicago 1971.

Yiannias J., The Refectory paintings of Mouth Athos: An Interpretation, [in:] The Byzantine Tradition after the Fall of Constantinople, ed. IDEm, Charlottesville-London 1991, p. 269-340, 290.

Антонов Д., МАйзульс М., Демоны, монстры и грешники в пространстве древнерусской иконограбии, Оди 2010/2011, р. 144-198.

Антонов Д., МАйзульс М., Анатомия ада: Путеводитель по древнерусской визуальной демонологии, Москва 2014.

Апокрифы Древней Руси: тексты и исследования, еd. В. Мильков, Москва 1997.

БАКАловА Е., За апотропейната сила на Божието слово и образ (легендата за Авгар в изкуството), [in:] Средновековният човек и неговият свят. Сборник в чест на 70-та годишнина на проф. Казимир Попконстантинов, Велико Търново 2014, р. 339-358.

БАРсов Е., О Тивериадском море, ЧИОИДР 2, 1886, р. 5-8.

Библия Василия Кореня. 1692-1696, Москва 1983.

Гергова И., Духовни образи. Руски илюстриран синодик, София 2014.

Димитрова Д., Някои наблюдения върху литературните особености на апокрифа "Слово за Адам и Ева", СЛ 11, 1982, р. 56-66.

Димитрова Д., Сказание за Тивериадското море. Текстологично изследване и критическо издание [SMSB 4], София 2014. 
Димитрова-МАринова Д., Богомильская космогония в древнеславянской литературной традиции, [in:] От Бытия к Исходу. Отражение библейских сюжетов в славянской и еврейской народной культуре, ed. В. Петрухин et al., Москва 1998, p. 38-58.

Иванов Й., Богомилски книги и тегенди, София 1970.

Истрин В., Откровеніе Мефодія Патарскаго и апокрифическія Видюнія Даніила в византійской и славяно-русской литературах: изсльдованіе и тексты, Москва 1897.

КАЧАЛОва И., МАЯСова Н., ЩЕННИКОва Л., БЛаговещенскИй собор Московского Кремля: К 500-летию уникального памятника русской культуры, Москва 1990, p. 61-64, ill. 178.

Квливидзе Н., Сотворение мира и история Адама и Евы в росписи Успенского собора Свияжского монастыря: к проблеме интерпретации сакрального пространства в русском искусстве XVI в., [in:] Древнерусское искусство. Идея и образ. Опыты изучения византийского и древнерусского искусства, Москва 2009, р. 343-366.

Кильдышев А., Фрески церкви Воскресения на Дебре в Костроме, Кострома 1996.

Комашко Н., КАткова С., Костромская икона ХІІ-ХІХ веков: Свод русской иконописи, Москва 2004.

Куюмджиева М., Изображението на Св. Троица в наоса на иърквата „Рождество Христово” в Арбанаси - иконограбски прототипи и съдържание, СЛ 43-44, 2010, p. 209-235.

МАрковић Ј., МАрковит М., Циклус Генезе и старозаветни фигуре у параклису св. Димитрија, [in:] Зидно сликарство Дечана. Граћа и студије, Београд 1995, p. 324-330.

Марковић М., Марковит Ј., Циклус Генезе и Старозаветне фигуре у параклису Св. Димитрија, [in:] Зидно сликарство манастира Дечана. Грађа и студије, еd. В. Ј. Ђурит, Београд 1995, p. 323-352.

Милтенова А., Маргиналност, интертекстуалност, паратекстуалност в българската сред-

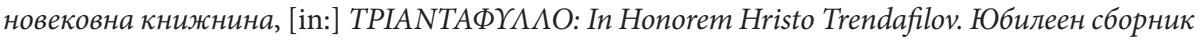
сборник в чест на 60-годишнината на проф. д.фил.н. Христо Трендафилов, еd. V. РANAYотоv, Шумен 2013, p. 128-150.

Милтенова А., Текстологически наблюдения върху два апокрифа: Апокрифен ичикъл за кръстното дърво, приписван на Григорий Богослов, и апокрифа за Адам и Ева, СЛ 11, 1982, p. 35-55.

Михеев С., Кто писал «Повесть временных лет»?, Москва 2011.

Мусакова Е., Надписи и изображения Шестоднева в болгарских рукописях и иерковной живописи XVII-XIX вв, [in:] От Бытия к Исходу. Отражение библейских сюжетов в славянской и еврейской народной культуре, ed. В. Петрухин et al., Москва 1998, p. 118-129.

Палея Толковая по списку сделанному в Коломне 1406 г., Москва 1892.

Попов А., Книга Бытия небеси и земли: Палея историческая с приложением сокращенной Палеи Русской редакиии, ЧИОИДР 1, 1881.

ПрАшков Л., Църквата “Рождество Христово” в Арбанаси, София 1979.

ПреобРАЖЕНСКИЙ А., О стиле и времени создания росписи собора Успенского монастыря в Свияжске, [in:] Лазаревские чтения. Искусство Византии, Древней Руси, Западной Евроnыl, Москва 2009, р. 268-308.

Пыпин А., Памятники старинной русской литературы, издаваемые Графом Григорием Кушелевымб-Безбородко. Выпуск третій. Ложныя и отреченныя книги русской старины, собранныя А. Н. Пьпинымъ, Санкт-Петербург 1862.

САкович А., Народная гравированная книга Василия Кореня, Москва 1983. 
София. Премудрость Божия. Каталог выставки русской иконописи XIII-ХІХ веков из собраний музеев России, Москва 2000.

Стара българска литература. 1. Апокрифи, еd. Д. ПЕткАнова, София 1981.

Творения иже во святых отиза нашего Василия Великого архиеп. Кесарии Каппадокийской, t. 1-3, Санкт-Петербург 1911, t. 2.

Творения Святого Отиза Нашего Иоанна Златоуста, архиепископа Константинопольского, в русском переводе. vol. 2, pars 1, ed. А. Лопухин, Санкт-Петербург 1896, p. 270-289.

Успенский Б., Борис и Глеб: восприятие истории в древней Руси, Москва 2000.

УСпенский П., Ерминия или наставление в живописном искусстве, составленное иеромонахом и живописием Дионисием Фурноаграфиотом. 1701-1733 год, Киев 1868 [TKDA 1868, t. 1, 2, 4].

ШАХматов А., Повесть временных лет и ее источники, ТОДЛ 4, 1940.

Яцимирский А., Библиографический обзор апокрифов в южнославянской и русской письменности (Списки памятников), fasc. 1. Апокрифы ветхозаветные, Петроград 1921.

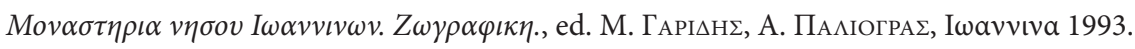

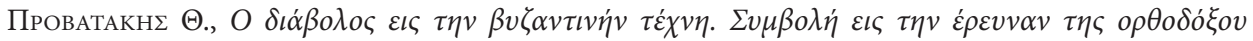

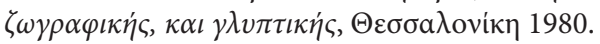

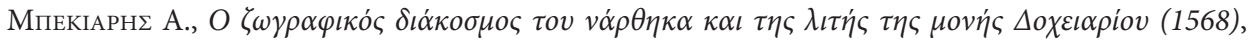

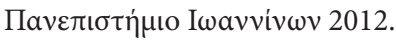

\begin{abstract}
Satan's interference in the events described in the first chapters of the book of Genesis and in the life of the protoplasts is not mentioned at all in the biblical text. This happens, however, in pseudo-canonical texts. The article is a short survey on the apocryphal accounts that mention Satan and their influence on art. The main focus is put on the inclusion of the image of Satan behind Cain's figure in a number of depictions of the scene The Murder of Abel in the Russian art of the $16^{\text {th }}$ and $17^{\text {th }}$ centuries. The possible links between this visual motif with several literary sources is examined, among them the Short and the Explanatory Palaea, the Tale of Bygone Years (Povest' vremennykh let or Primary Chronicle), Russian recensions of the apocryphon The Sea of Tiberias, and of The Revelation of Pseudo-Methodius of Patara. In addition, some instances of the same visual decision in Balkan art are pointed out and their connection to Russian models is underlined.
\end{abstract}

Keywords: Satan, Devil, Genesis, Cain, Abel, Eastern Orthodox art, pseudo-canonical texts, apocrypha.

\title{
Margarita Kuyumdzhieva (Sofia)
}

Institute of Art Studies, Bulgarian Academy of Sciences 21 Krakra Str., Sofia 1000, Bulgaria margaritakj@gmail.com 


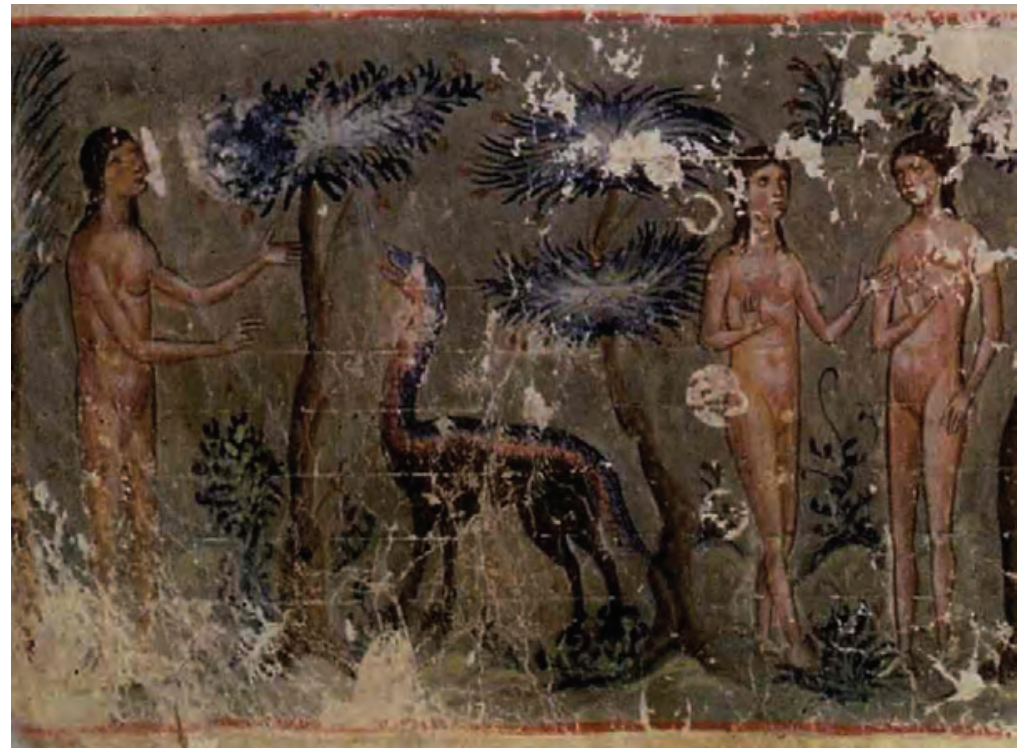

Fig. 1. The image of the snake-camel in the scene of the Temptation, Octateuch, Constantinople, ca. 1125-1155, Rome, Bibl. Apost. Vat., gr. 746, fol. 37v (source: K. Weitzmann, M. Bernabò, R. TaRAsconi, The Byzantine Octateuchs, 1: Text; 2. Plates (Illustrations in the Manuscript of the Septuagint, 2.), Princeton 1999).

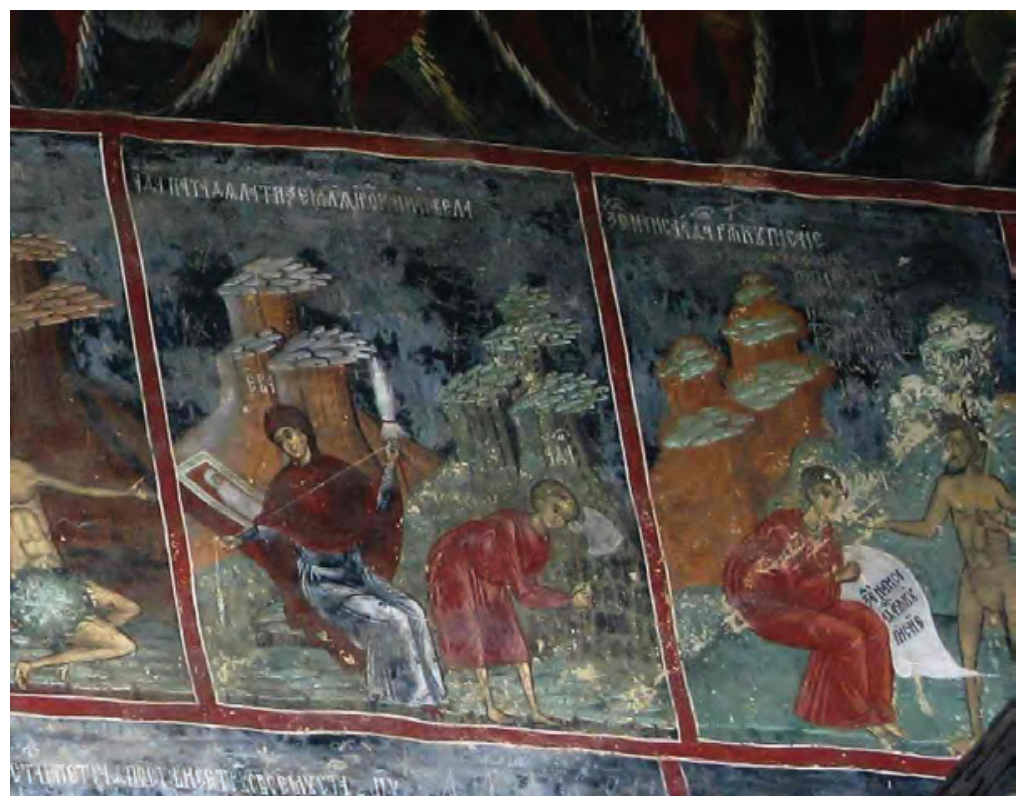

Fig. 2. Adam's Contract with Satan, north façade of the catholicon, Sucevița Monastery (1596), Romania. 


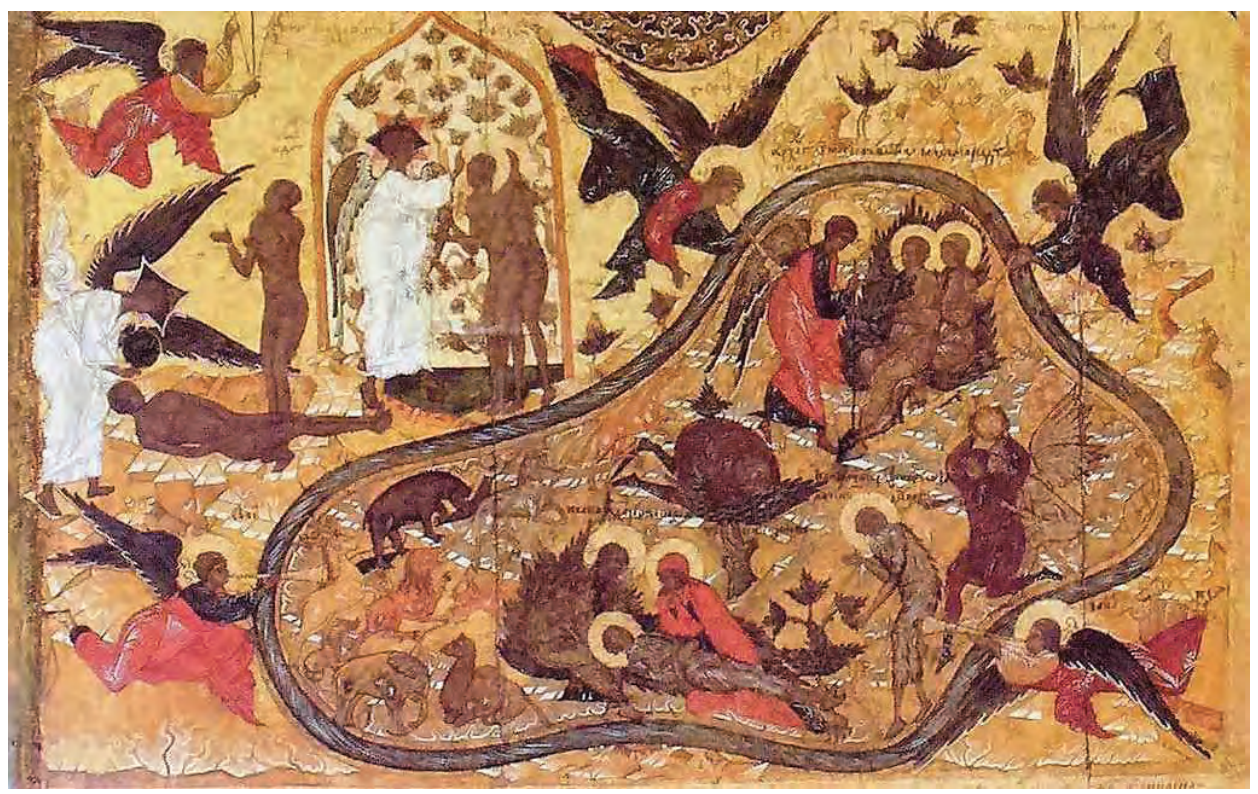

Fig. 3. The quadripartite icon from the Annunciation Cathedral of the Moscow Kremlin (Moscow, 1547-1551), detail of the upper left field, named “И почи Бог в день седьмый” (“And God rested on the seventh day") representing scenes from the story of Adam, Eve, Cain and Abel, among them The Murder of Abel, where the Devil is represented behind Cain (source: И.Я. КАчаловА, Н.А. МАясовА, Л.А. ЩЕНниковА, Благовещенский собор Московского Кремля = The Аппипсіаtion Cathedral of the Moscow Kremlin: К 500-летию уникального памятника русской культуры, Москва: Искусство, 1990).

Fig. 4. Detail of the icon with the composition "И почи Бог в день седьмый” (“And God rested on the seventh day"), $17^{\text {th }}$ century, The Church Historical and Archeological Museum in the Ipatiev Monastery, Kostroma, Russia (source: Н. КОМАшКО, С. Каткова, Костромская икона ХІІ-ХІХ веков: Свод русской иконописи, Москва 2004).

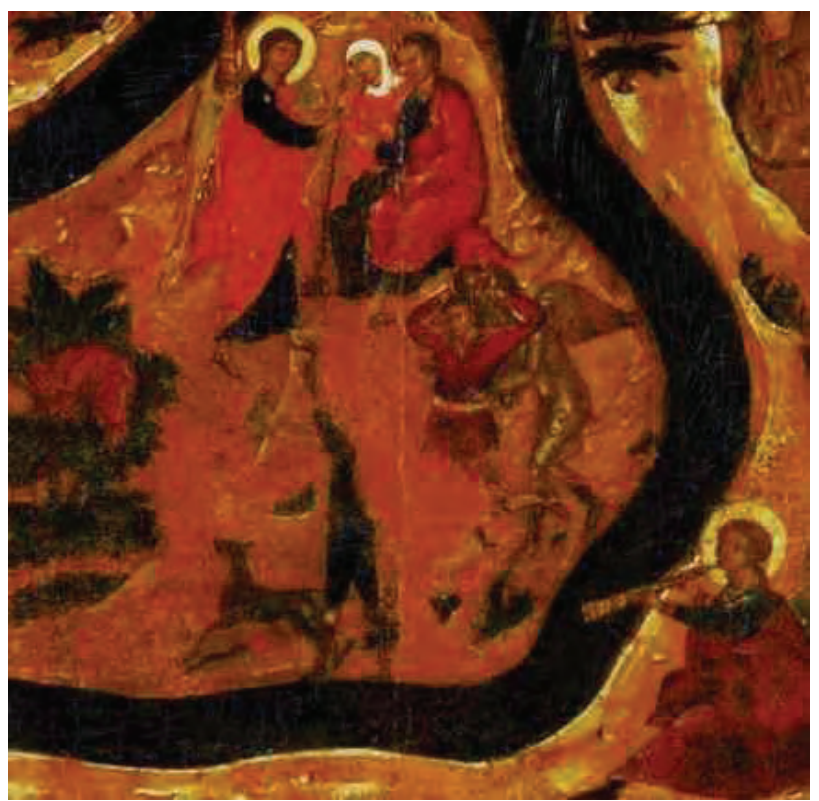




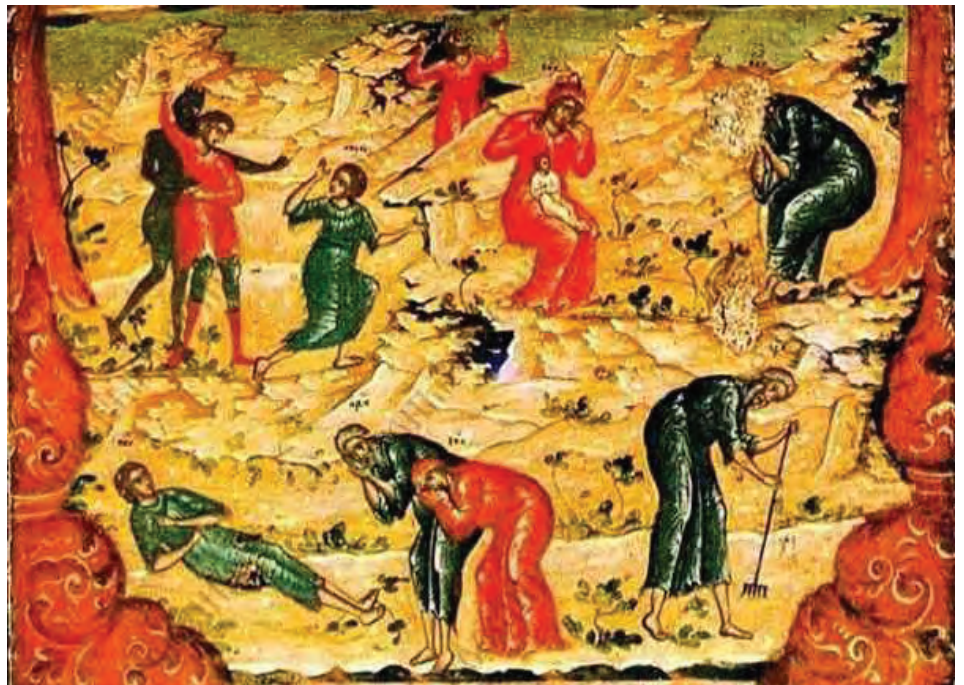

Fig. 5. Detail from an icon, Russia, end $17^{\text {th }}$ century, Inv. № ПЗМ-368, ЖТ-2, part of the south doors of the iconostasis of St. Nicholas Monastery, PereslavlZalessky (source: Переславль-Залесский государственный историко-архитектурный и художественный музей-заповедник, via http://www.icon russia.ru/icon/detail.php?ID=6026).

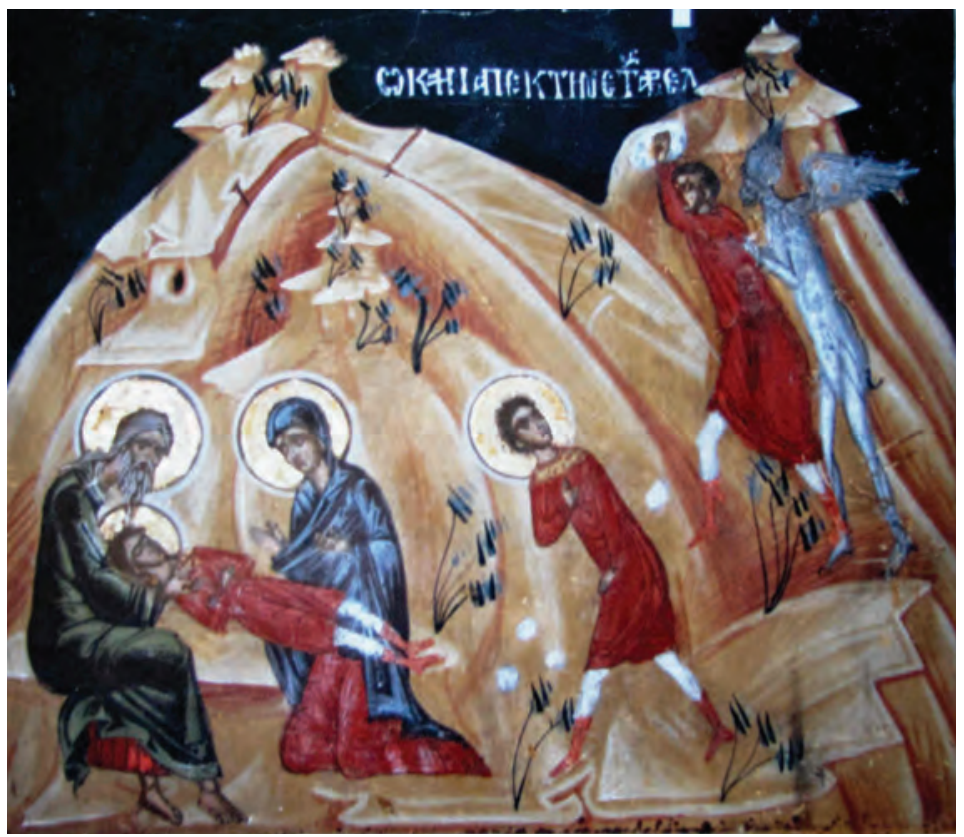

Fig. 6. The Devil behind Cain's figure in the frescoes of the Nativity church (1643) in Arbanassi village near Turnovo, Bulgaria. 